\title{
STUDY ON REMOVAL OF COPPER, TIN AND ARSENIC FROM IRON ORE, SCRAP AND STEEL IN THE LIGHT OF THE LATEST STATE OF METALLURGICAL TECHNOLOGY
}

\author{
BADANIE USUWANIA MIEDZI, CYNY I ARSENU Z RUDY ŻELAZA, ZEOMU I STALI \\ W ŚWIETLE NAJNOWSZEGO STANU TECHNIKI METALURGICZNEJ
}

The study investigates the ability to remove copper, tin and arsenic from iron ore, scrap and liquid steel based on the literature and thermodynamic calculations using the FactSage 7.2 software. Methods of removing $\mathrm{Cu}$, Sn and As from iron-bearing materials, feasible in industrial conditions in the near term, were selected. Simulation tests with the use of the FactSage 7.2 software showed that under reduced pressure conditions $\mathrm{Cu}$ and $\mathrm{Sn}$ can be removed from the steel bath, while As evaporation is not possible. Laboratory tests were carried out, including the removal of Sn and $\mathrm{Cu}$ in the process of degassing of liquid steel in a deep vacuum in a vacuum induction furnace and the removal of $S n$ from iron ore in the sintering process. Under conditions of deep vacuum (below $40 \mathrm{~Pa}$ ), high temperature $\left(1670^{\circ} \mathrm{C}\right)$ and a correspondingly long vacuum treatment time (over 30 minutes), the efficiency of removing the copper and tin contents from the liquid steel of approximately 14 and $17 \%$ respectively was obtained. The iron ore sintering test with a high $\mathrm{Sn}$ content showed the effectiveness of reducing the Sn content during this process, amounting to approx. $30 \%$.

Keywords: steel, vacuum degassing, iron ore, sintering, copper, tin, arsenic
Zbadano możliwości usuwania miedzi, cyny i arsenu z rudy żelaza, złomu i ciektej stali na podstawie literatury oraz termodynamicznych obliczeń za pomoca oprogramowania FactSage 7.2. Wybrano sposoby usuwania Cu, Sn i As z materiatów żelazonośnych możliwe do realizacji $w$ warunkach przemystowych $w$ najbliższej perspektywie czasowej. Badania symulacyjne z zastosowaniem oprogramowania FactSage 7.2 wykazaty, $\dot{z} e$ w warunkach obniżonego ciśnienia można usunać Cu i Sn z kapieli stalowej, natomiast nie jest możliwe odparowanie As. Przeprowadzono próby laboratoryjne, obejmujace usuwanie Sn i Cu w procesie odgazowania ciekłej stali $w$ głębokiej próżni $w$ próżniowym piecu indukcyjnym oraz usuwanie Sn z rudy żelaza $w$ procesie spiekania. W warunkach gtębokiej próżni (poniżej $40 \mathrm{~Pa}$ ), wysokiej temperatury $\left(1670^{\circ} \mathrm{C}\right.$ ) i odpowiednio dtugiego czasu obróbki próżniowej (powyżej 30 minut) uzyskano skuteczności usunięcia zawartości miedzi $i$ cyny $w$ ciektej stali, wynoszace odpowiednio okoto 14 i 17\%. Próba spiekania rudy żelaza z wysoka zawartościa Sn wykazata skuteczność zmniejszenia zawartości Sn w czasie tego procesu, wynoszaca ok. $30 \%$.

Słowa kluczowe: stal, odgazowanie próżniowe, ruda żelaza, spiekanie, miedź, cyna, arsen

\section{INTRODUCTION}

Continuous reduction of $\mathrm{CO}_{2}$ emissions to the atmosphere during steel production will increase the use of post-amortisation and shredded scrap in the steel smelting process, increasing its contamination mainly with copper and tin. On the other hand, the continuous increase in steel production will result in an increasing consumption of ores, which will contain less and less Fe and more Sn and As. These elements are harmful in steel due to the deterioration of its hot forming ability and the deterioration of the mechanical properties of steel products. Therefore, industrial methods of removing these elements from ores, as well as from scrap and liquid steel are being sought.

The purpose of the study was to investigate the possibility of removing copper, tin and arsenic from iron ore, scrap and liquid steel in the light of the latest state of metallurgical technology, based on the analysis of methods for removing these elements, presented in available publications and on the basis of thermodynamic simulations carried out using the FactSage 7.2 software and original laboratory tests. The paper presents a selection of methods of removing $\mathrm{Cu}, \mathrm{Sn}$ and As from iron-bearing materials, possible to be carried out in industrial conditions in the nearest time perspective. 


\section{REVIEW OF THE LITERATURE ON THE PRIOR ART OF REMOVING CU, SN, AS FROM IRON ORE, SCRAP AND LIQUID STEEL}

Copper cannot be removed from scrap-based steel by conventional refining in a steel refining process. Several methods of reducing the $\mathrm{Cu}$ content in steel were proposed, namely the improvement of scrap sorting, dilution of contaminated input with directly reduced iron, as well as mechanical or chemical pre-treatment of the scrap [1]. Considerable research efforts have been made to develop pyrometallurgical techniques. On a laboratory scale, it was confirmed that copper can be removed during treating the steel bath with sulphide fluxes, but treatment under decreased vacuum is a more promising method. This method of selective evaporation of copper has been successfully tested on a laboratory scale [2-4]. Research is currently underway to optimise the operation of the shredder in relation to the copper content of scrap. Preliminary results show that copper content can be controlled by changing the way the shredder works. With regard to sorting scrap, copper was found to be most efficiently removed by manual sorting. Portable optical emission spectrometers, image analysis and X-ray fluorescence (XRF) are used for sorting and identifying scrap components. Many already available commercial devices, both portable and hand-held, ensure the selection of scrap with purity above $98 \%$ Fe [1].

Tin, as one of the main residual elements in steel, occurs in the form of segregation, which affects the thermoplasticity, tempering brittleness and susceptibility of steel products to heat treatment [5]. Using the FactSage7.2 thermochemical program, the influence of calcium, oxygen and sulphur on the removal of tin was investigated [5], and it was found that under reducing conditions it was possible to remove tin from the liquid steel with calcium, after exceeding its critical content in the steel. This critical calcium content increases as the oxygen and sulphur content of the steel increases. Hence, before starting the removal of tin with calcium, the oxygen and sulphur content of the steel should be reduced as much as possible. The process of removing tin with calcium is facilitated by the lowest possible temperature of the liquid steel. Calcium is introduced into the steel through slag made of calcium compounds: $\mathrm{CaO}, \mathrm{CaC}_{2}$ and $\mathrm{CaF}_{2}$. A process of removing tin from liquid steel that is promising for the industry is low-pressure treatment $[6,7]$. The vapour pressure of $\mathrm{Sn}$ at the temperature of liquid steel is several dozen times greater than that of Fe. At a temperature of the liquid steel of $1600^{\circ} \mathrm{C}$, pressure of $10 \mathrm{~Pa}$ and treatment time of $42 \mathrm{~min}$, the efficiency of Sn removal was above $99 \%$ in laboratory conditions. Due to the availability of mechanical devices for producing deep vacuum in industrial steel degassing plants, this method seems quite promising for use. Tin removal increases with the evaporation of volatile tin-carriers such as sulphides, oxides and chlorides. The increased content of carbon and silicon in liquid steel also accelerates the evaporation of tin [8]. The highest rate of tin evaporation in the elemental state was observed in liquid iron alloys with high silicon content, which allowed reducing tin content by at least $22 \%$ [8] in the technological process. Hence, the greatest benefits in the recycling of tinplate scrap are observed in the production of ferrosilicon.

In the future, iron ores with the content of $30-55 \% \mathrm{Fe}$, with an increased content of $\mathrm{Sn}$, in the range of $0.2-1.2 \%$ should be expected in the trade [6]. These ores are main- ly magnetites, and tin is in the form of cassiterite $\left(\mathrm{SnO}_{2}\right)$. Tin removal in the enrichment process of such ores is less than $30 \%$, and takes place in various roasting processes, namely: sulphurisation and evaporation, chlorination and evaporation, and reduction evaporation. These processes, due to their high harmful impact on the environment, are currently tested only on a laboratory scale.

There are large deposits of iron ore containing tin in the world (China). The Sn content in the ore concentrate after multiple enrichment amounts to more than $0.08 \%$ [9]. In raw materials, as evidenced by the current metallurgical practice, tin is difficult to remove in blast furnace and steelmaking processes. Previous studies [9] show that some of the tin can be removed from zinc-bearing iron ore concentrates with the reduction sintering process. The following $\mathrm{SnO}_{2}$ reactions take place during reduction sintering:

$$
\begin{aligned}
& \mathrm{SnO}_{2}+\mathrm{CO}=\mathrm{SnO}+\mathrm{CO}_{2} \\
& \mathrm{SnO}_{2}+2 \mathrm{CO}=\mathrm{Sn}+2 \mathrm{CO}_{2}
\end{aligned}
$$

SnO evaporates easily at a temperature greater than $900^{\circ} \mathrm{C}$. The reduction of iron oxides and tin oxides begins when the temperature rises above $500^{\circ} \mathrm{C}$, which means that the reduction and evaporation reactions occur practically before approaching the final sintering stage, in the range from $850^{\circ} \mathrm{C}$ to $1100^{\circ} \mathrm{C}$. This short time of keeping at a higher temperature and a high sintering end temperature (greater than $1100^{\circ} \mathrm{C}$ ) have a detrimental effect on $\mathrm{Sn}$ removal due to the reduction of $\mathrm{SnO}_{2}$ to metallic tin.

Due to the fact that this process can be difficult to implement in the industry due to the difficult control of its temperature, a more effective and economical sulphide roasting process is considered [10], in which tin phases are transformed mainly into SnS and removed by evaporation.

Arsenic also has a detrimental effect on the properties of steel, namely it increases the hot surface brittleness, lowers plasticity and impact strength [11, 12]. The chemical affinity of arsenic to oxygen is lower than that of iron to oxygen [12] and therefore it is difficult to remove by oxidation in the steelmaking process. Theoretically, it is possible to remove As from liquid iron by means of high consumption of $\mathrm{Al}$ and $\mathrm{Ca}-\mathrm{Fe}$ alloys or rare earth metals, but it also requires prior deep deoxidation and desulphurisation, which makes the costs of removing As in industrial conditions very high [12]. Arsenic can be removed from arsenic-bearing ore in the process of roasting or sintering using the volatility of arsenic and its compounds [12]. It is also important to recover arsenic from dusts from these processes, preventing further As accumulation and environmental contamination. Previous studies $[12,13]$ showed that arsenic can be economically removed from iron ores containing arsenopyrite by roasting in air or in a slightly reducing atmosphere containing nitrogen. Arsenic is removed in the roasting process in the form of gaseous $\mathrm{As}_{2} \mathrm{O}_{3}$, and residual arsenic reacts in the ore with oxides to form arsenates $\left(\mathrm{FeAsO}_{4}, \mathrm{AlAsO}_{4}, \mathrm{Ca}_{3}\left(\mathrm{AsO}_{4}\right)_{2}\right)$, which can only be removed during roasting in a reducing atmosphere. Arsenic removal in an oxygen atmosphere occurs mainly according to the following reaction (3) [12]:

$$
2 \mathrm{FeAsS}+5 \mathrm{O}_{2}(\mathrm{~g})=\mathrm{Fe}_{2} \mathrm{O}_{3}+\mathrm{As}_{2} \mathrm{O}_{3}(\mathrm{~g})+2 \mathrm{SO}_{2}(\mathrm{~g})
$$

The rate of arsenic removal increases with increasing temperature from 700 to $1000^{\circ} \mathrm{C}$ and is slower with roasting in air compared to roasting in nitrogen atmosphere. 


\section{THERMODYNAMIC CALCULATIONS OF CU, SN AND AS REMOVAL USING THE FACTSAGE 7.2 SOFTWARE}

Numerical simulations of tin, copper and arsenic removal from liquid steel under reduced pressure conditions were performed using the Equilib module of the FactSage 7.2 thermochemical program.

Input data for the numerical simulation are shown in Table 1.
Due to the fact that the post-amortisation, shredded scrap contains both $\mathrm{Cu}$ and $\mathrm{Sn}$, the simulations were performed in two variants:

- removal of tin and copper that occur together in a steel bath

- arsenic removal.

The results of the calculations are presented in the graph of the content of elements in the steel bath as a function of the pressure above the bath (Fig. 1), as well as in the summary table with the values of pressure necessary to achieve the assumed final level of tin and copper (Table 2).

Table 1. Input data for thermochemical calculations

Tabela 1. Dane wyjściowe do obliczeń termochemicznych

\begin{tabular}{|c|c|c|c|c|c|c|c|c|c|c|}
\hline \multirow{2}{*}{ Variant $\square$ Wariant } & \multicolumn{9}{|c|}{ Chemical composition = Skład chemiczny, [\%] } & \multirow{2}{*}{$\begin{array}{c}\text { Pressure } \\
\text { Ciśnienie } \\
\text { [Pa] }\end{array}$} \\
\hline & C & Si & [0] & s & Al & Sn & As & $\mathbf{C u}$ & Temp., $\left[{ }^{\circ} \mathrm{C}\right]$ & \\
\hline As & $0.40-1.00$ & $0.20-0.60$ & $\begin{array}{l}0.002 \\
0.020\end{array}$ & $\begin{array}{l}0.06 \\
0.12\end{array}$ & $\begin{array}{l}0.02 \\
0.08\end{array}$ & & $\begin{array}{l}0.04 \\
0.08\end{array}$ & & & 15 \\
\hline $\mathrm{Cu}+\mathrm{Sn}$ & $0.40-1.00$ & $0.20-0.60$ & $\begin{array}{l}0.002 \\
0.020\end{array}$ & $\begin{array}{l}0.06 \\
0.12\end{array}$ & $\begin{array}{l}0.02 \\
0.08\end{array}$ & $\begin{array}{l}0.04 \\
0.08\end{array}$ & & $\begin{array}{l}0.40 \\
0.80\end{array}$ & $\begin{array}{l}1600 \\
1680\end{array}$ & 25 \\
\hline
\end{tabular}

Table 2. Required temperatures and pressures to remove $\mathrm{Cu}$ and $\mathrm{Sn}$ to final contents

Tabela 2. Wymagane temperatury i ciśnienia do usunięcia Cu i Sn do końcowych zawartości

\begin{tabular}{|c|c|c|c|c|}
\hline \multirow[b]{2}{*}{$\begin{array}{c}\text { Temperature } \\
\text { Temperatura } \\
{\left[{ }^{\circ} \mathrm{C}\right]}\end{array}$} & \multicolumn{4}{|c|}{ Pressure Ciśnienie [Pa] } \\
\hline & $\begin{array}{l}\text { Beginning of rapid } \mathrm{Cu} \\
\text { evaporation } \text { Początek } \\
\text { szybkiego parowania } \mathrm{Cu}\end{array}$ & $\begin{array}{l}\text { End of } \mathrm{Cu} \text { evaporation } \\
\text { (total Cu removal) } \\
\text { Koniec parowania } \mathrm{Cu} \\
\text { (całkowite usunięcie } \mathrm{Cu} \text { ) }\end{array}$ & $\begin{array}{l}\text { Required for achieving } \\
\text { final content } \text { Wymagane } \\
\text { do uzyskania końcowej } \\
\text { zawartości } \\
\text { Cu }=0.1 \%\end{array}$ & $\begin{array}{l}\text { Required for achieving } \\
\text { final content } \\
\text { Wymagane do uzyskania } \\
\text { końcowej zawartości } \\
\text { Sn }=0.02 \%\end{array}$ \\
\hline \multicolumn{5}{|c|}{ 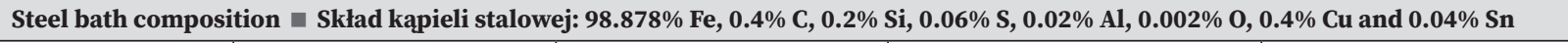 } \\
\hline 1600 & $\sim 14$ & $\sim 8$ & $\sim 9.3$ & $\sim 11$ \\
\hline 1680 & $\sim 32$ & $\sim 20$ & 23 & 25 \\
\hline \multicolumn{5}{|c|}{ Steel bath composition — Skład kąpieli stalowej: $98.878 \%$ Fe, 0.1\% C, 0.6\% Si, 0.12\% S, 0.08\% Al, 0.02\% 0, 0.8\% Cu and 0.08\% Sn } \\
\hline 1600 & 24 & 6 & $\sim 9.4$ & $\sim 11$ \\
\hline 1680 & 50 & 17.5 & $\sim 24$ & 22 \\
\hline
\end{tabular}

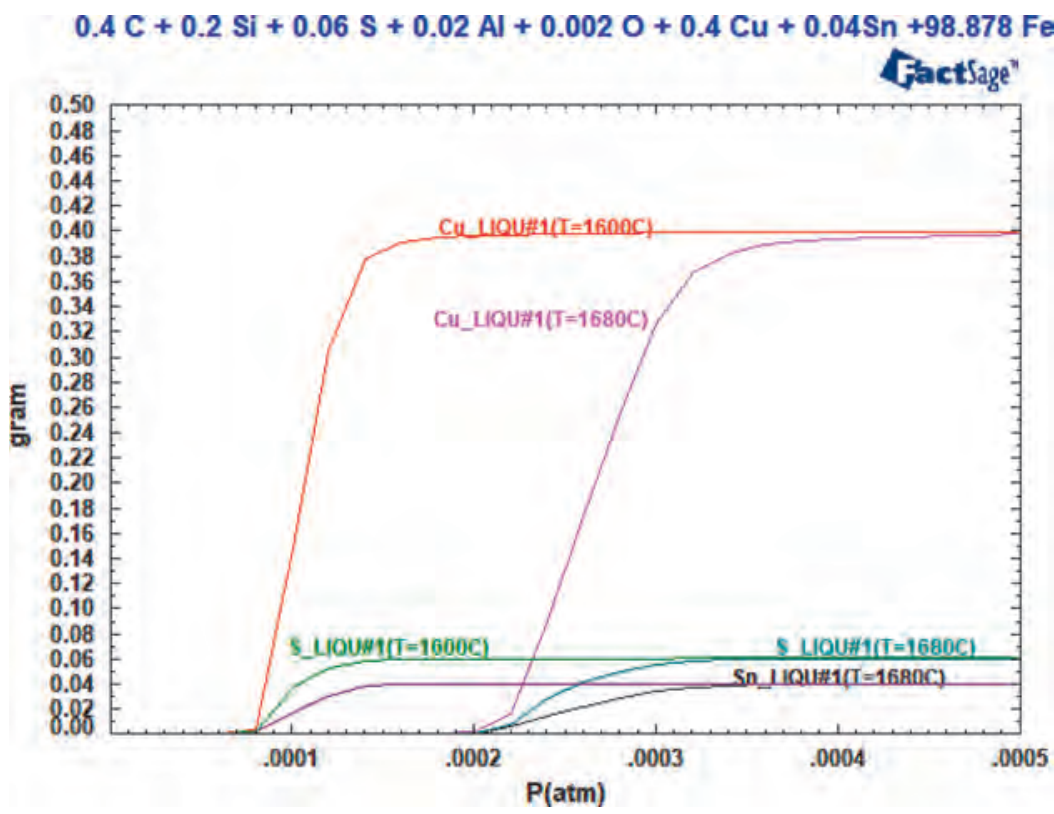

Fig. 1. Change of the content of $\mathrm{Cu}, \mathrm{Sn}$ and $\mathrm{S}$ in steel bath with the above-mentioned chemical composition as a function of pressure above the bath at a constant temperature of $1600^{\circ} \mathrm{C}$ and $1680^{\circ} \mathrm{C}$

Rys. 1. Zmiana udziału Cu, Sn i S w kąpieli stalowej o podanym wyżej składzie chemicznym w funkcji ciśnienia nad kąpielą w stałej temperaturze $1600^{\circ} \mathrm{C}$ i $1680^{\circ} \mathrm{C}$ 
The graphs also take sulphur into account, as it is an important element increasing the activity of $\mathrm{Cu}$ and $\mathrm{Sn}$ in liquid metal in a vacuum, as well as steel contamination that can be removed under reduced pressure.

In order to compare the evaporation parameters for copper and tin depending on the bath composition, Table 2 summarises the pressure values at which the assumed final level of copper and tin will be achieved, i.e. 0.1 and 0.02 weight $\%$, respectively.

The following observations result from the numerical simulations and the analysis of the results presented in Fig. 1 and Table 2:

- Under reduced pressure conditions, both $\mathrm{Cu}$ and $\mathrm{Sn}$ can be removed from a steel bath with the composition: $0.40-1.00 \% \mathrm{C} ; 0.20-0.60 \% \mathrm{Si} ; 0.06-0.12 \% \mathrm{~S}$ and $0.02-0.08 \%$ $\mathrm{Al}$, but it is not possible to evaporate As.

- The higher the temperature of the liquid steel, the lower the required negative pressure and the greater the dynamics (rate) of evaporation of copper and tin from the steel bath.

- Obtaining the content of $0.1 \% \mathrm{Cu}$ in the steel bath with the above-mentioned chemical composition at $1600^{\circ} \mathrm{C}$ requires reducing the pressure above the bath to approximately $9.5 \mathrm{~Pa}$, and at $1680^{\circ} \mathrm{C}$ to approximately $24 \mathrm{~Pa}$.

- Obtaining the content of $0.02 \% \mathrm{Sn}$ in the steel bath with the above-mentioned chemical composition at $1600^{\circ} \mathrm{C}$ requires reducing the pressure above the bath to approximately $7 \div 8 \mathrm{~Pa}$, and at $1680^{\circ} \mathrm{C}$ to approximately $20 \div 22 \mathrm{~Pa}$.

- No influence of the chemical composition of the steel bath within the analysed limits (including: 0.002 to $0.02 \%$ $\mathrm{O}$ and 0.02 to $0.08 \% \mathrm{~S}$ ) on the evaporation of $\mathrm{Cu}$ and $\mathrm{Sn}$ from it was found.

\section{COURSE AND DISCUSSION OF LABORATORY TEST RESULTS}

Laboratory tests included laboratory smelting of steel in a vacuum induction furnace with a crucible capacity of $30 \mathrm{~kg}$ of liquid metal for simultaneous removal of $\mathrm{Cu}$ and Sn from liquid steel and a sintering test of a mixture containing tin dioxide in a laboratory sintering pot.

\subsection{LABORATORY TEST OF CU AND SN REMOVAL FROM LIQUID STEEL UNDER REDUCED PRESSURE}

Sample material. In the test, armco iron was used as input to the induction furnace, with the following chemical composition in weight \%: C - 0.020; $\mathrm{Mn}-0.11$; $\mathrm{Si}-0.06$; P $0.004 ; \mathrm{S}-0.005 ; \mathrm{Cu}-0.04 ; \mathrm{Al}-0.059$, in the form of bars, dimensions $40 \times 60 \times 500(\mathrm{~mm})$ and the following alloying additives of metallic or elemental purity, in weight \%: Si (99.5), Mn (99.8), C (98.0), S (99.9), Cu (99.9), Sn (99.9), Al (99.99).

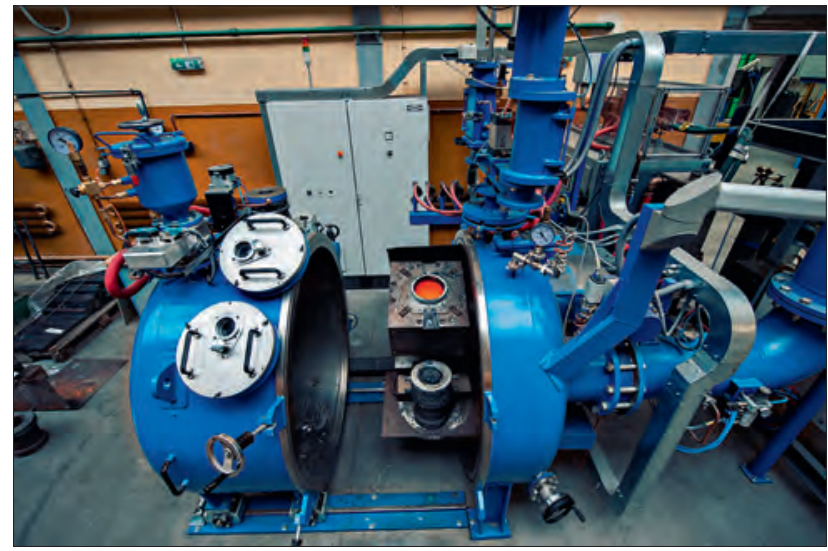

Fig. 2. VIM LAB 30-75 vacuum induction furnace Rys. 2. Widok próżniowego pieca indukcyjnego typu VIM LAB 30-75

Methodology. The test was carried out in a VIM 30 vacuum induction furnace, shown in Fig. 2, with a crucible capacity of $30 \mathrm{~kg}$ of liquid metal. The crucible was made of a refractory spinel $\left(\mathrm{MgO}-\mathrm{Al}_{2} \mathrm{O}_{3}\right)$ material. After melting the input and supplementing the additives, the bath was heated to $1660^{\circ} \mathrm{C}$ and subjected to vacuum degassing at the pressure maintained at $27 \mathrm{~Pa}$, for 30 minutes, with continuous heating of the metal bath. The temperature was then adjusted to the casting temperature $\left(1612^{\circ} \mathrm{C}\right)$ and an ingot weighing $24 \mathrm{~kg}$ was poured from which samples were taken for chemical analysis.

Table 3 summarises the results of a laboratory test of $\mathrm{Cu}$ and $\mathrm{Sn}$ removal from liquid steel in a vacuum induction furnace.

The analysis of the results collected in Table 3 shows that under the conditions of deep vacuum (about $30 \mathrm{~Pa}$ ), high temperature $\left(1670^{\circ}\right)$, during vacuum treatment (for 30 minutes), the contents of copper and tin in the liquid steel decreased by 14 and $16.6 \%$, respectively. In order to effectively lower the content of these elements to trace values, a vacuum of less than $20 \mathrm{~Pa}$ is required, which is difficult to achieve under laboratory furnace conditions.

\subsection{LABORATORY TEST OF SN REMOVAL FROM ORE IN THE SINTERING PROCESS}

The following materials were used in the sintering test:

- iron ore concentrate, with the composition given in Table 4 , in the amount of $78 \%$ of the weight of the input mixture

Table 4. Chemical composition of iron ore, [weight \%]

Tabela 4. Skład chemiczny rudy żelaza, [\% masy]

\begin{tabular}{|c|c|c|c|c|c|c|}
\hline $\mathbf{F e}_{\text {total }}$ & $\mathbf{F e}^{++}$ & $\mathbf{S i O}_{2}$ & $\mathbf{C a O}$ & $\mathbf{A l}_{\mathbf{2}} \mathbf{O}_{3}$ & $\mathbf{M g O}$ & $\mathbf{S}$ \\
\hline 65.57 & 26.69 & 7.99 & 0.15 & 0.18 & 0.37 & 0.035 \\
\hline
\end{tabular}

Table 3. Chemical compositions of samples from laboratory steel smelting with Cu and Sn removal and the degree of Cu and Sn removal Tabela 3. Składy chemiczne próbek z laboratoryjnego wytopu stali z usuwaniem Cu i Sn oraz stopień usunięcia Cu i Sn

\begin{tabular}{|c|c|c|c|c|c|c|c|}
\hline Analysis $\square$ Analiza [wt \%] & C & Mn & Si & $\mathbf{S}$ & $\mathrm{Cu}$ & Sn & $\mathbf{A l}_{\text {total }}$ \\
\hline - computational $\square$ obliczeniowa & 0.45 & 0.23 & 0.20 & 0.065 & 0.40 & & 0.13 \\
\hline $\begin{array}{l}\text { - prior to treatment in deep vacuum } \\
\text { przed obróbką w głębokiej próżni }\end{array}$ & 0.26 & 0.16 & 0.17 & 0.062 & 0.5 & 0.12 & 0.004 \\
\hline - after vacuum, from ingot $\square$ po próżni, z wlewka & & & & & 0.43 & 0.10 & \\
\hline Degree of removal a Stopień usunięcia, [\%] & & & & & 14 & 16.6 & \\
\hline
\end{tabular}


- tin carrier - cassiterite $\left(\mathrm{SnO}_{2}-99.99 \%\right)$, in the amount of $0.27 \%$ of $\mathrm{Sn}$ in the weight of the input mixture,

- limestone, with the composition given in Table 5, in the amount of $5.7 \%$ of the weight of the input mixture,

Table 5. Chemical composition of limestone, [weight \%]

Tabela 5. Skład chemiczny kamienia wapiennego, [\% masy]

\begin{tabular}{|c|c|c|c|c|c|}
\hline $\mathbf{C a O}$ & $\mathbf{S i O}_{\mathbf{2}}$ & $\mathbf{A l}_{\mathbf{2}} \mathbf{O}_{\mathbf{3}}$ & $\mathbf{M g O}$ & $\mathbf{S}$ & $\mathbf{F e}_{\text {total }}$ \\
\hline 53.92 & 0.94 & 0.34 & 0.59 & 0.15 & 1.25 \\
\hline
\end{tabular}

- burnt lime, with the composition given in Table 6, in the amount of $0.5 \%$ of the weight of the input mixture

Table 6. Chemical composition of burnt lime, [weight \%]

Tabela 6. Skład chemiczny wapna palonego, [\% masy]

\begin{tabular}{|c|c|c|c|c|}
\hline $\mathbf{C a O}$ & $\mathbf{S i O}_{\mathbf{2}}$ & $\mathbf{A l}_{\mathbf{2}} \mathbf{O}_{\mathbf{3}}$ & $\mathbf{M g O}$ & $\mathbf{F e}_{\text {total }}$ \\
\hline 95.40 & 0.50 & 0.07 & 0.30 & 0.63 \\
\hline
\end{tabular}

- coke breeze containing $83.3 \% \mathrm{C}$ and $11.80 \%$ ash with the composition given in Table 7 , in the amount of $7.5 \%$ of the weight of the input mixture

Table 7. Chemical composition of coke breeze ash, [weight \%] Tabela 7 Skład chemiczny popiołu koksiku, [\% masy]

\begin{tabular}{|c|c|c|c|c|c|c|}
\hline $\mathbf{F e}_{\text {total }}$ & $\mathbf{F e}^{++}$ & $\mathbf{S i O}_{\mathbf{2}}$ & $\mathbf{C a O}$ & $\mathbf{A l}_{\mathbf{2}} \mathbf{O}_{\mathbf{3}}$ & $\mathbf{M g O}$ & $\mathbf{S}$ \\
\hline 6.5 & 0.35 & 36.14 & 4.54 & 18.76 & 2.04 & 0.61 \\
\hline
\end{tabular}

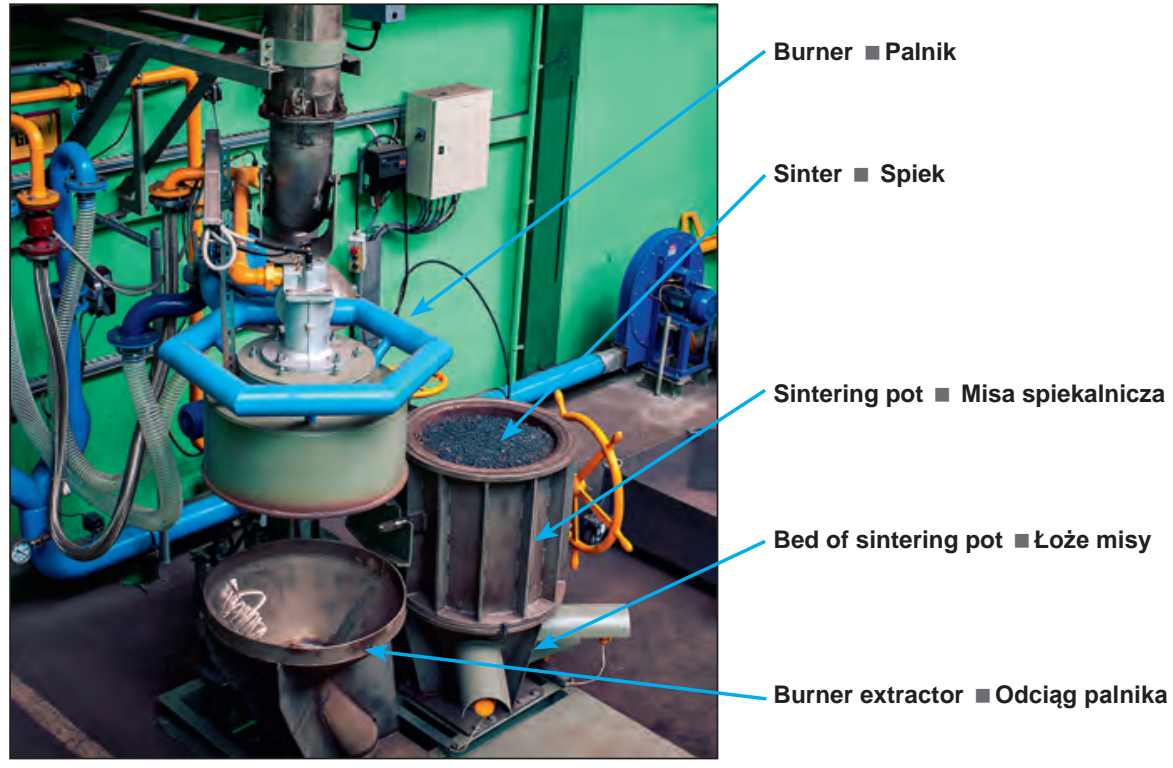

Fig. 3. Laboratory sintering installation with a sinter in the sintering pot

Rys. 3. Widok laboratoryjnej instalacji spiekalniczej ze spiekiem w misie spiekalniczej

Table 8. Analysis of $\mathrm{Sn}, \mathrm{Fe}, \mathrm{Fe}^{3+}$ and $\mathrm{Fe}^{2+}$ content in sinter in various places along the height of the sintered layer Tabela 8. Analiza zawartości $\mathrm{Sn}, \mathrm{Fe}, \mathrm{Fe}^{3+} \mathrm{i} \mathrm{Fe}{ }^{2+} \mathrm{w}$ spieku, w różnych miejscach po wysokości warstwy spiekanej

\begin{tabular}{|c|c|c|c|c|}
\hline Substance content $\varpi$ Zawartość substancji, [wt \%] & Sn & $\mathbf{F e}$ & $\mathrm{Fe}_{2} \mathrm{O}_{3}{ }^{*}$ & FeO \\
\hline - computational in input $\mathbf{~ o b l i c z e n i o w a ~ w e ~ s a d z i e ~}$ & 0.36 & & & \\
\hline - in sinter sample from the top $\mathbf{w}$ próbce spieku z góry & 0.26 & 61.85 & 32.90 & 37.23 \\
\hline - in sinter sample from $1 / 2$ of layer's height $\square \mathrm{w}$ próbce spieku z $1 / 2$ wysokości warstwy & 0.28 & 60.74 & 34.37 & 35.19 \\
\hline - in sinter sample from the bottom $\mathbf{w}$ w próbce spieku z dołu & 0.25 & 60.04 & 39.37 & 26.57 \\
\hline Degree of $S n$ removal $\approx$ Stopień usunięcia $S n^{* *},[\%]$ & 26.9 & & & \\
\hline
\end{tabular}

Notes: ${ }^{*}$ - other iron forms, including $\mathrm{Fe}_{2} \mathrm{O}_{3}$ and metallic $\mathrm{Fe} ;{ }^{* *}$ - mean value 


\section{CONCLUSIONS}

Based on the research performed, the following conclusions can be drawn:

1. Numerical simulations with the use of the FactSage 7.2 software showed that under reduced pressure conditions both $\mathrm{Cu}$ and $\mathrm{Sn}$ can be removed from the steel bath, while As evaporation is not possible, whereas:

- the higher the temperature of the liquid steel, the lower the required negative pressure and the greater the dynamics (rate) of evaporation of copper and tin from the steel bath,

- effective reduction of the content of these elements to trace values: $\mathrm{Cu}<0.10 \%$; $\mathrm{Sn}<0.02 \%$ requires a vacuum of less than $20 \mathrm{~Pa}$ at $1670^{\circ} \mathrm{C}$.

2. Under the conditions of laboratory recasting in a vacuum induction furnace during a 30 -minute vacuum treatment with a minimum pressure over the bath of $27 \mathrm{~Pa}$ and a maximum temperature of $1670^{\circ} \mathrm{C}$, a decrease in $\mathrm{Cu}$ content by $14 \%$ and $\mathrm{Sn}$ by approximately $17 \%$ was obtained.
3. The iron ore sintering test with a high Sn content showed that it was possible to effectively reduce its content in this process. It is assumed that the obtained tin removal result of $28 \%$ can be improved by selecting the optimal sintering conditions, including the composition of the sintering mixture, the amount of reducing agent and the sintering temperature.

4. The conducted attempts to remove tin and copper from the steel bath, as well as to remove tin in the sintering process, do not yet provide grounds for the development of assumptions for industrial tests for the removal of $\mathrm{Sn}$ and $\mathrm{Cu}$. It can only be stated that these processes can be used in industrial conditions in the future, as nowadays industrial devices for vacuum treatment of liquid steel in a ladle are manufactured with a vacuum production capacity below $20 \mathrm{~Pa}$. The extracted and captured Sn, $\mathrm{SnO}$ and $\mathrm{Cu}$ vapours are deposited on the walls of the vacuum chamber and on the filter, and can be recycled in non-ferrous metallurgy for the recovery of $\mathrm{Sn}$ and $\mathrm{Cu}$.

Article from the implementation of research work financed by the Ministry of Education and Science, agreement: No. 11/CE- Ins./2020 of 18.06.2020.

\section{REFERENCES}

[1] Ch.T. Satyendra. Steel Scrap and Scrap Sorting and Preparation Processes, 2017. [Online] Available at: https://www.ispatguru. com/steel-scrap-and-scrap-sorting-and-preparation-processes/ [Accessed on: 20.04.2020]

[2] L. Blacha, J. Łabaj. Temperature impact on copper evaporation from liquid iron. Arch. Mater. Sci. Eng., 2011, 51 (2), p. 103-106.

[3] J. Łabaj, B. Oleksiak, G. Siwiec. Study of Copper Removal from Liquid Iron. Metalurgija, 2011, 50 (4), p. 265-268.

[4] J. Łabaj. Usuwanie miedzi i cyny ze stopów żelaza. Hutnik - Wiadomości Hutnicze, 2018, 85 (3), p. 84-87.

[5] X. Zhang, G. Ma, M. Liu, Z. Li, M. Song. Thermodynamic analysis of the effect of molten steel compositions on tin removal. Results in Physics, 2020, 16, 102862.

[6] X. Zhang, G. Ma, M. Liu, Z. Li. Removal of Residual Element Tin in the Ferrous Metallurgy Process: A Review. Metals, 2019, 9 (8), 834.

[7] J. Lipart, J. Łabaj, M. Słowikowski, D. Jama. Effects of pressure on the rate of tin evaporation from liquid iron. Archives of Metallurgy and Materials, 2014, 59 (2), p. 825-828.
[8] L. Savov, S. Tu, D. Janke. Methods of Increasing the Rate of Tin Evaporation from Iron-based Melts. ISIJ International, 2000, 40, (7), p. 654-663.

[9] Z. Su, Y. Zhang, B. Liu, J. Chen, G. Li, T. Jiang. Behaviour of $\mathrm{SnO}_{2}$ in the Tin-bearing Iron Concentrate during a Reduction Sintering Process. J. Min. Metall. Sect. B - Metall. 2017, 53 (1), p. 67-74.

[10] Y. Yu, L. Li, X. Sang. Removing Tin from Tin-bearing Iron Concentrates with Sulfidation Roasting Using High Sulfur Coal. ISIJ International, 2016, 56, (1), p. 57-62.

[11] W. Xin, B. Song, Z. Yang, Y. Yang, L. Li. Effect of Arsenic and Copper+Arsenic on High Temperature Oxidation and Hot Shortness Behavior of C-Mn Steel. ISIJ International, 2016, 56, (7), p. 12321240.

[12] R. Cheng, H. Zhang, H. Ni. Arsenic Removal from ArsenopyriteBearing Iron Ore and Arsenic Recovery from Dust Ash by Roasting Method. Processes 2019, 7 (10), 754.

[13] A.M. Schwarz. Process for Removing Arsenic from Iron Ore. [Online] Available at: https://patents.google.com/patent/ US3427149A/en [Accessed on: 25.06.2020]. 